\title{
A GRASS ROOT ORIENTED URBAN PLANNING APPROACH TO UPLIFT THE SOCIO-ECONOMIC FACET OF A CITY USING 2D AND 3D GIS: CASE STUDY ON MEHMEDABAD CITY, INDIA
}

\author{
Saurabh Gupta ${ }^{1 .}$, , Chiranjay Shah ${ }^{2}$, Devshri Shah ${ }^{2}$, Prithvi Deore ${ }^{2}$, Sayantan Majumdar ${ }^{1}$, Abhisek Maiti ${ }^{1}$,Shashwat Shukla ${ }^{1}$, \\ Jignesh Mehta ${ }^{2}$, Mansi Shah ${ }^{2}$ \\ ${ }^{1}$ Geo-Informatics Department, Indian Institute of Remote Sensing, Indian Space Research Organization, Dehradun, India - (gupta, \\ s.majumdar, maiti, shukla)@student.utwente.nl \\ ${ }^{2}$ Faculty of Planning, CEPT University, Ahmedabad, India - (chiranjay.shah.bplan12, devshri.shah.bplan12, prithvi.deore.bplan12, \\ jignesh.mehta)@cept.ac.in, mansi.arch@gmail.com
}

Commission IV, WG IV/4

KEY WORDS: Urbanisation, GIS, Urban Planning, City Development Plan, Population Projection, Socio-economic Infrastructure

\begin{abstract}
:
Being a developing nation, India is facing an array of problems owing to the huge population shift from rural to urban areas, thereby leading to an increasing urbanisation trend since the $1980 \mathrm{~s}$. As a result, the process of urban planning in India is extremely tedious and requires lots of manual intervention. Although the recent developments in GIS have immensely helped urban planners, extensive ground survey is still a big challenge in the context of Indian cities. In this work, the study area has been chosen as Mehmedabad which is a Tier-3 city in the state of Gujarat. A rigorous grass root oriented ground survey involving each and every household of Mehmedabad has been utilised for both requirement elicitation and site-suitability purposes. With the aid of both 2D and 3D GIS, a city development plan has been proposed for the year 2031. The planning process incorporated population projection, water supply demand, sewage discharge and road network analysis for building robust development control regulations which were essential to improve the socio-economic aspects of Mehmedabad. Additionally, cost estimations for each of the proposed sectors have been carried out so as to maintain an appropriate budget for uplifting the existing infrastructures of the city.
\end{abstract}

\section{INTRODUCTION}

The term "urbanisation" refers to the shift of population from rural to urban areas. It is the process by which a large number of people become permanently concentrated in relatively smaller areas, thereby leading to the growth of cities. Although this process of urbanisation is universal in nature, there is a stark contrast in the pattern of urbanisation between the developed and developing nations, as the majority of the population in the developed countries live in urban areas, while the bulk of the population in the developing countries belong to the rural areas (Bhagat \& Mohanty, 2009).

\subsection{Urbanisation in India}

Traditionally, the notion of a town or city is usually perceived to be a free-standing built up area having well established administrative, commercial, social and civic functions. It also provides a multitude of facilities as compared to the rural counterparts, such as, convenient and accessible amenities (e.g., banks, educational institutes, post offices, police stations, hospitals etc.) and proper infrastructure that includes roads, public transport, water, sewage etc. (World Vision International, 2016). In the Indian context, as per the latest census report (Census of India, 2011a), the criteria that label a place as urban includes the following: 1) All places with a municipality, corporation, cantonment board or notified town area committee, etc. 2) All other places that consist of a minimum population of 5000 , at least $75 \%$ of the male working population engaged in non-agricultural pursuits and a minimum population density of 400 persons/ sq. km.

\footnotetext{
* Corresponding author
}

Places belonging to the former category are known as statutory towns, whereas the latter ones in the aforementioned categorization are called census towns. In order to estimate the population of urban residents who dwell outside the municipal boundary, the Indian census uses the concept of "Urban Agglomeration" (UA). An essential feature of a UA is that it is made up of the population concentrated at the core of the municipal area, as well as the population of the contiguous towns and associated urban outgrowths (OGs). OGs are viable units (such as villages or hamlets or enumeration blocks consisting of villages and hamlets) surrounding but not within a statutory town that are suitably large and already urbanized (railway colony, military campus etc.) (Bhagat \& Mohanty, 2009; Census of India, 2011a).

\subsection{Recent Trends and Urban Growth Patterns}

The urban population in India at the beginning of the $20^{\text {th }}$ century was around 25 million and constituted only $10.8 \%$ of the total population in 1901. Since then, the urban population has increased manifolds and as per the census report 2011, more than 377 million (31.16\% of the total population) people live in urban areas (Bhagat \& Mohanty, 2009; Census of India, 2011a). This increasing decadal growth has been illustrated in Figure 1 wherein an exponential trend is depicted. On the contrary, the rural growth in India, as shown in Figure 2.c, has gradually decreased over the years for both Empowered Action Group (EAG) and non-EAG states of India (Census of India, 2011b). This clearly attributes to the rising trend of urbanisation in India primarily due to the population migration from rural to urban areas as well as the expansion of economic opportunities in urban areas (Figure 2.a and 2.b). As a consequence of this drastic change in urbanisation pattern, Indian cities are facing 
severe problems related to urban sprawl, housing, transport, sanitation, slum areas and environmental degradation in the form of air, water, and soil pollution. In order to cope with these growing challenges, the Government of India has taken several initiatives such as Smart City mission, Swachh Bharat Abhiyan (SBA), Atal Mission for Rejuvenation and Urban Transformation (AMRUT), Heritage City Development and Augmentation Yojana (HRIDAY), Pradhan Mantri Awas Yojana-Urban (PMAY-U), Urban Transport and many more (MOHUA, 2017). One of the key factors associated with such city development plans is the population growth. Several studies show that by quantitatively assessing the historical growth trends, statistically robust population growth projection models can be built using important variables like birth rate, mortality rate, migration growth etc. (Colby \& Ortman, 2015; Ehrlich \& Holdren, 1971; Peterson \& Donaldson, 1984). At their core, all these initiatives heavily rely on the efficient use of geospatial data for which the role of GIS is of paramount importance.

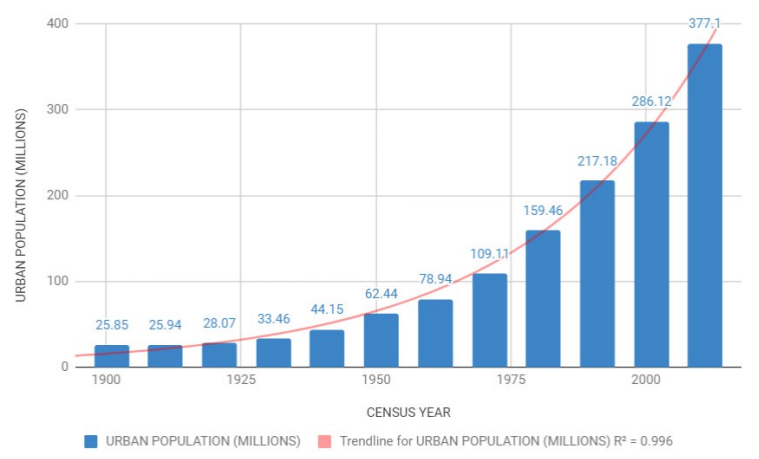

Figure 1. Decadal Urban Growth in India

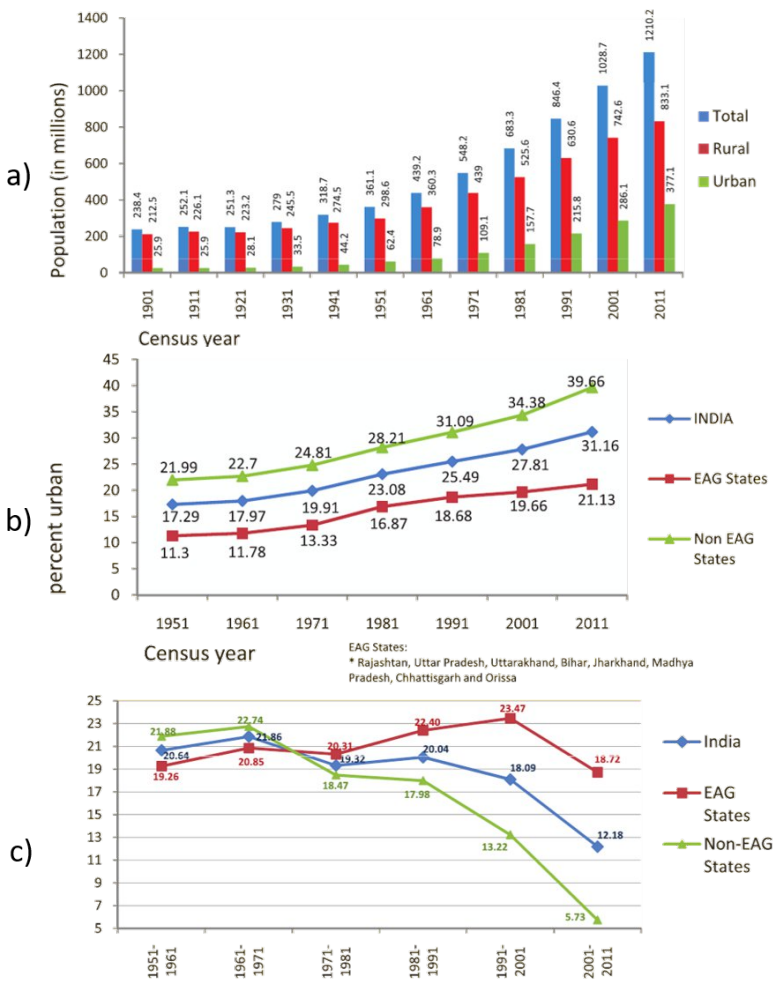

Figure 2. a) Total Population by Residence b) Percentage of Urban Population c) Rural Growth Rates in India (Census of India, 2011b)

\subsection{GIS as a Component of Urban Planning}

A characteristic feature of cities in developing nations like India is the fragmented nature of their spatial organisation. UAs consisting of planned as well as illegal and slum settlements, exhibit a type of continuously discontinuous pattern that is cumbersome and sometimes impossible to handle with the traditional approaches of urban planning (Balbo, 1993). In the current scenario, the tremendous growth of the Internet of Things (IoT) and the Internet itself, has led to the standardized exchange of voluminous data, thereby facilitating the utilization of geospatial technologies like Geographic Information System (GIS) in several domains particularly in the urban planning paradigm. GIS primarily acts as an analytical and modelling tool and can be applied on an ad hoc basis to a wide array of problems that are prominent in this field. The use of the major components of GIS like data management, visualisation, spatial analysis, and modelling varies according to the task specified by the respective urban planner wherein different planning scales and strategies necessitate the usage of different data sets and techniques. Moreover, the role of GIS also depends on the stage of urban planning and when fused with remote sensing data, can be used to perform spatio-temporal analysis like land use land cover (LULC) changes. In addition to this, with the help of GIS, it is possible to carry out site-suitability analysis whereby the urban planners are able to create and manage resource inventories consisting of in situ and remotely sensed data, identify the solution space for future development (for which robust and flexible modelling and projection tools are already built-in to the GIS or can be seamlessly added as plugins) and analyse the existing trends of population and socio-economic factors (Yeh, 2005).

An important aspect of urban planning is data visualisation which is, in turn, a part of the urban designing process. Urban designing is concerned with the shape and surface of all kinds of urban elements (Xia \& Qing, 2006). In order to fully utilise the computing power that is available nowadays, significant research efforts related to 3D city modelling have been made so as to provide urban planners and target users a realistic view of the cities which was not possible with the traditional 2D GIS (Beatriz, Molnar, Griffith, \& Salhi, 2018; Brasebin, Perret, Mustière, \& Weber, 2018; Dell'Unto et al., 2016; Gong et al., 2018; Koziatek, Dragićević, \& Li, 2016; Polys, Newcomb, Schenk, Skuzinski, \& Dunay, 2018; Scianna \& Ammoscato, 2010; Xia \& Qing, 2006). Using 3D GIS, urban planners can now simulate the real world scenario more accurately, such as determining which floors would be affected by waterlogging inside a building on the advent of a natural disaster like a flood (Adda et al., 2010). Another intriguing study incorporated a model based approach to automatically extract buildings from high resolution satellite images (M. Rumor, V.Coors, E.M. Fendel, 2007). However, developing these models requires a lot of manual intervention and as a result, is costlier than the corresponding 2D or $2.5 \mathrm{D}$ ones. Still, with the emergence of newer open source softwares for three dimensional generation and representation of structures (Scianna \& Ammoscato, 2010) the overall cost of $3 \mathrm{D}$ GIS projects is expected to reduce in the coming days.

\subsection{City Development Plan}

A city development plan (CDP) acts a perspective as well as a vision for the future growth of a city. It is a multi-stage process involving rigorous and in-depth analysis of the current demographic, economic, infrastructure and other important aspects of a city. The main goal of a CDP is to create 
economically productive, efficient, equitable and responsive cities wherein the main focus is laid on the strategic development of socio-economic infrastructures. It provides the foundation for the cities to participate in urban reforms thereby allowing direct investment into them. It also facilitates a logical and consistent framework under which respective projects are identified and implemented and can be henceforth used for investment decision planning (MOHUA, 2005). As per the sixth central pay finance of Government of India, cities are categorised into Tier-1, Tier-2, and Tier-3 types on the basis of population.

In the present study, a development plan for Mehmedabad, Gujarat, India has been proposed based on the existing pattern of the city by utilizing both 2D and 3D GIS. The prime focus of this scheme is to improve the existing scenario of the city by leveraging the heritage sites, road network and quality of life. Suitable development control regulations (DCR) have been framed to achieve these objectives.

\section{STUDY AREA AND BASE DATA ACQUISITION}

\subsection{City Context}

Mehmedabad is a Tier-3 city, an Indian town, and municipality, situated on the banks of Vatrak River in Kheda district of Gujarat state. It is located at $22.83^{\circ} \mathrm{N} 72.77^{\circ} \mathrm{E}$ and lies in between two major cities of Ahmedabad (state capital of Gujarat) and Baroda. The contextual map of Mehmedabad displayed in Figure 3.a illustrates the exact location of this city. It is $34 \mathrm{~km}$ away from Ahmedabad and has a functioning railway station. It also facilitates public as well as paratransit modes of transportation and provides moderate inter and intra city connectivity. The city also consists of various heritage sites of historic importance such as Roza Rozi, Bhammariyo Kuvo, Dhudhiya Vaav, Shree Siddhivinayak temple, gates of old fabric and dilapidated house. The surrounding villages of Mehmedabad, namely Pahad, Khatraj, Kachhai Katakpura and Virol are highlighted in Figure 3.b.

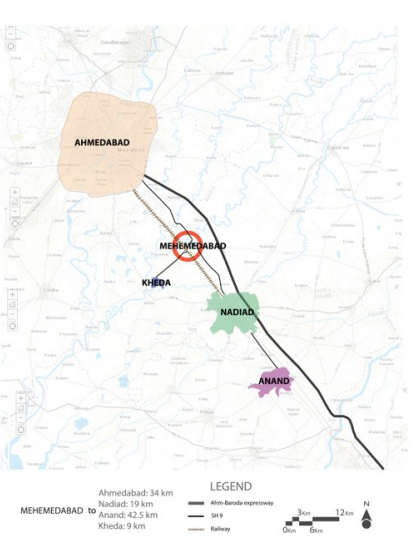

a)

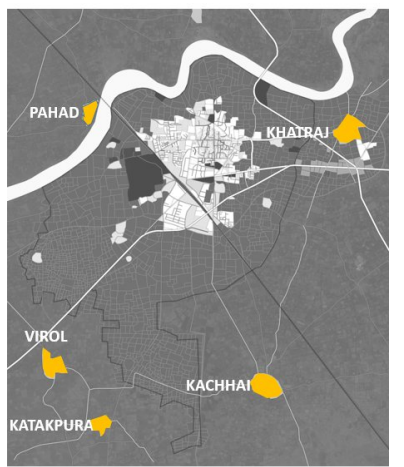

b)

Figure 3. a) Contextual map b) Surrounding villages of Mehmedabad

Mehmedabad is a part of Ahmedabad Urban Development Authority (AUDA). According to census 2011, the population of the city is 35368 . Mehmedabad has a low growth rate of $13 \%$ as compared to the natural growth rate of Gujarat (19\%). The overall demographic information of the city is described in Table 1.

\begin{tabular}{|l|c|}
\hline \multicolumn{2}{|c|}{ Basic Demographic Information } \\
\hline Area (sq.km) & 13.15 \\
No. of wards & 9 \\
No. of Households & 7348 \\
Population & 35368 \\
Male & 18207 \\
Female & 17161 \\
Literates (M) & 14664 \\
Literates (F) & 12337 \\
Main Worker & 10206 \\
Marginal Worker & 23386 \\
Sex Ratio & 943 \\
\hline
\end{tabular}

Table 1. Demographic information of Mehmedabad

\subsection{Base Data Acquisition}

The first step towards the data acquisition was to fetch satellite imagery for concocting the base map. The Cartosat-2 satellite map was then georeferenced and digitized into several layers to examine the existing scenario. The digitized base map which included buildings, road networks, heritage sites etc. was further taken on site for validation of individual households, heritage sites, roads, amenities, basic services and facilities in Mehmedabad. Moreover, it has been observed that the majority of the municipal area of the city contributes to agricultural land. This is portrayed in the land use zoning map represented in Figure 4.

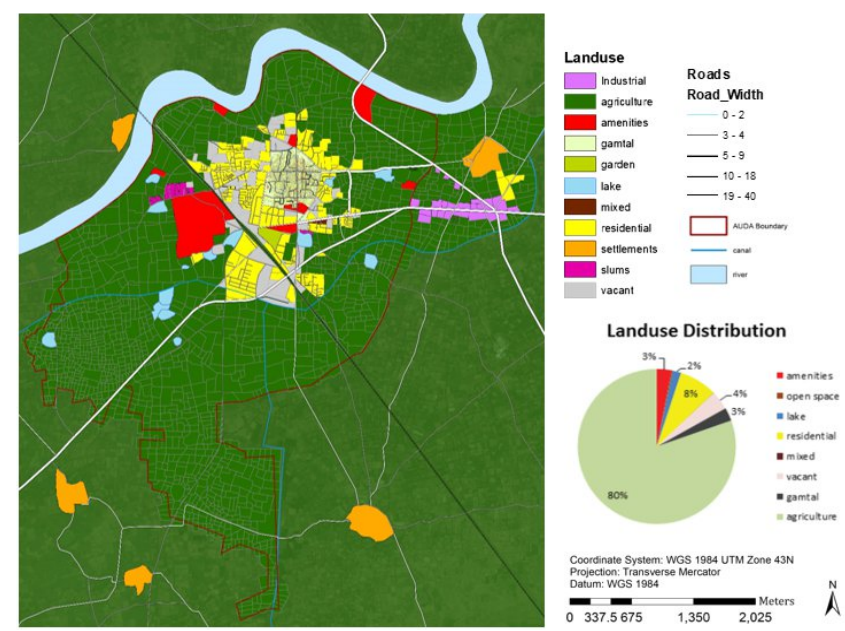

Figure 4. Existing Land Use Zoning

\section{METHODOLOGY}

In the initial phase of the study, the existing scenario of Mehmedabad was envisaged so as to analyse the relationship and interdependence amongst the macro and micro levels of the city. As a part of this analysis, the physical, social, economic and temporal facets of the urban fabric have been incorporated in the planning processes for a better understanding of the scales. Since the core part of Mehmedabad has major contributions towards the development of the city in terms of socio-economic aspects and also consists of the heritage sites, therefore it was necessary to connect the inner core to the outer one. The workflow followed during the entire urban planning process has been explained in Figure 5. In addition, various thematic maps such as water supply, sewage discharge, and road networks were generated to overcome the issues of the city. The workflow was carried out in four primary phases a) Concept Development b) Data Preparation c) SWOT Analysis 
d) Development Plan Generation. These are discussed in the following sub-sections.

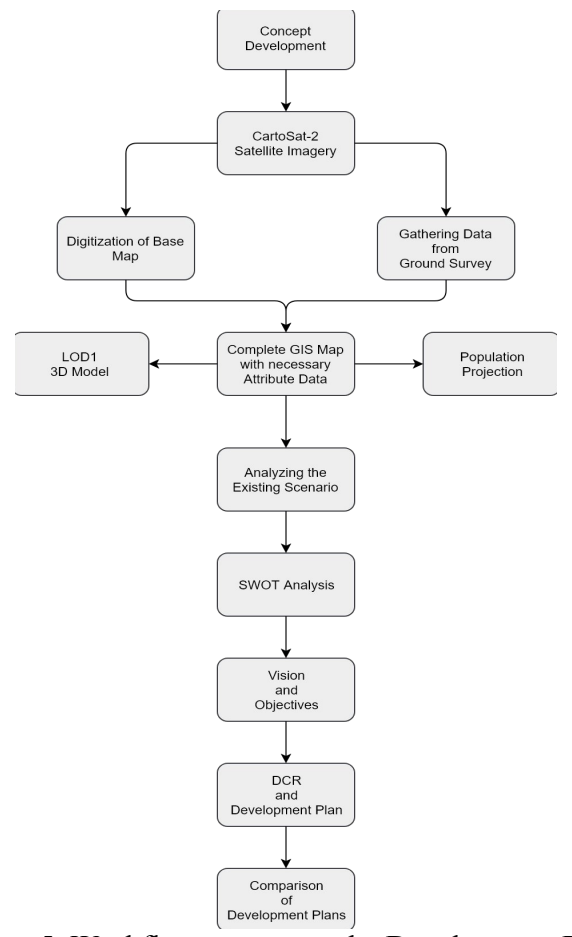

Figure 5. Workflow to prepare the Development Plan

\subsection{Concept Development}

In the initial phase of the study, the key factors which were thought to be essential for aiding the development plan generation have been considered. These included the heritage sites, commercial areas and both intra and intercity connectivity. The zoning systems for the conceptual land use were constructed following three phases of development. The first phase involved the upgradation of vacant lands with the subsequent ones building upon it. The phases are shown in Figure 6.
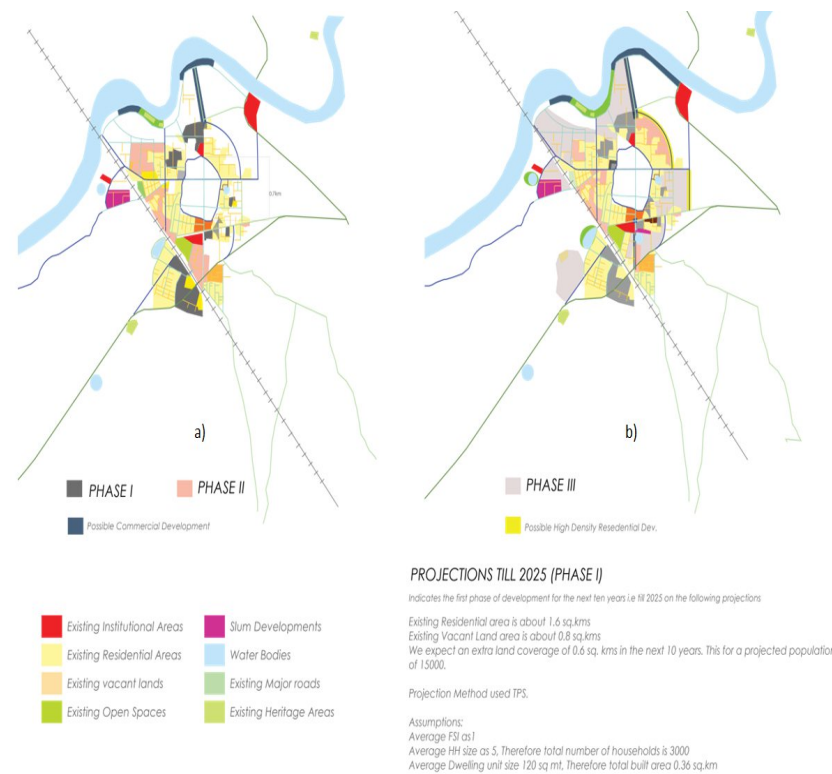

Figure 6. a) Concept maps of Phase I and II b) Concept map of Phase III

\subsection{Data Preparation}

Once the base data acquisition process was complete, then the first task was to connect the spatial and non-spatial data using ArcMap. All the relevant datasets were downloaded from AUDA, (2018) at 1:20000 scale. The projection system used in this case was UTM Zone $43 \mathrm{~N}$ with WGS 84 as the datum. The spatial data involved roads, building blocks, amenities (e.g., banks, educational institutes, post offices, police stations, hospitals etc.), basic infrastructure such as elevated storage reservoir (ESR), solid waste dump sites. On the other hand, the non-spatial data included the attributes of the spatial data such as name and type of the roads and amenities, land use type of the building and many more.

\subsection{SWOT Analysis}

In order to construct a robust and concrete development plan for the city, SWOT (Strength, Weaknesses, Opportunities, and Threats) analysis was carried out on the existing scenario. It has been proven to be a well-established analysis technique for strategic planning purposes and has been henceforth incorporated in this study (Dyson, 2004). At the outset, the data prepared from the extensive ground based survey and satellite images had been used to identify Mehmedabad's strengths and weaknesses which were then utilised to postulate a framework for recognizing the opportunities that the city could provide and the threats that would negatively impact the city's socioeconomic infrastructure. The entire analysis, performed using ArcGIS, has been illustrated in Figure 7.a wherein it can be observed that, despite providing an adequate regional connectivity to the commercial hubs and having a lively core area, the city suffers from community space encroachment and outward population migration to other cities due to the shortage of local occupations. Moreover, the city's rich cultural heritage sites, which could prove to be the major economic growth factor of the city, are poorly maintained and as a result, the city is gradually losing its identity. The only viable opportunities that the city presented were a walkable network in and around the core area (for improving the liveliness of the city), publicity and promotion of the heritage sites and nearby water bodies, and an increased commercial base for facilitating local skill development. The key points of the SWOT analysis are described as a chart in Figure 7.b.

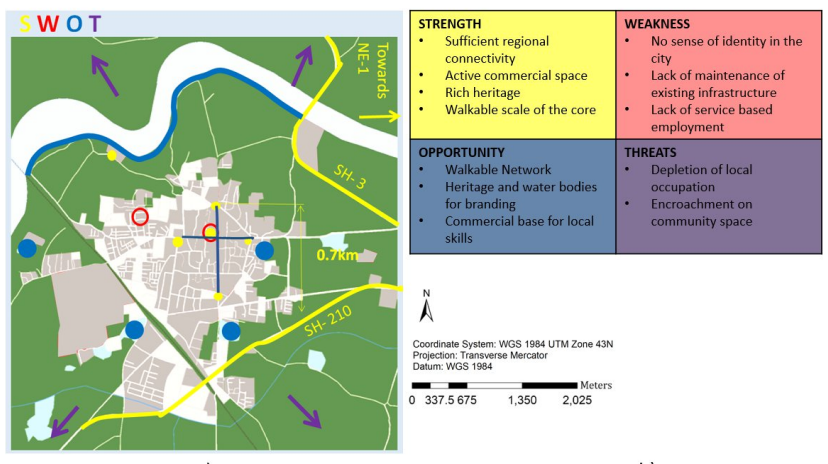

Figure 7. a) SWOT Analysis on Mehmedabad b) Key points of SWOT Analysis

\subsection{Development Plan Generation}

As part of the development plan (DP) preparation, the morphology of the city was studied. The DP acts as a catalyst for positive changes and progress in a strategic way of a city vis-a-vis achieve greater balance in all the areas to develop to 
their maximum potentials. The processes involved in the DP preparation were a) framing policies and formulation of development plan following Gujarat Development Control Regulations (AUDA, 2016), b) population projection till 2031. In order to successfully mitigate the ongoing issues faced by the city, several development control regulations (DCRs) were laid down (Table 2) whereby the concept of FSI has been utilised. The floor space index (FSI) is the ratio of the combined gross built-up area of all the floors to the total area of the building unit. The permissible FSI refers to the basic FSI allowable by the competent authority as a matter of right (AUDA, 2016). It helps to control the development happening in and around. In the case of Mehmedabad, the proposed FSI varies for different zones. For example, the FSI of the gamtal zone (old city) is 2 , whereas for commercial areas it is 0.9 . The conservation of the elements are otla, courtyard, openings, plot, and heights. The new development or the redevelopment of the existing house in this zone should be in such a way that it should have similarity and have the same sense of the old city and should only have residential, mercantile-1, and religious zones. The proposed FSI for each zones of Mehmedabad is illustrated in table 2. Here the DCR at macro level included mixed use corridor, residentialmixed zone (having the permissible use of residential units such as an apartment, semi-attached and detached dwelling units) and commercial zone (basic utility, shops restaurants, shopping center). In the residential-mixed zone, if the built use is only residential, then the FSI will be 1.2 and if the built use is mixed, an additional 0.3 FSI will be provided, wherein a maximum of ground $(\mathrm{G})+3$ floors can be built having open space of $8 \%$, parking within the plots.

\begin{tabular}{|c|c|l|}
\hline Zone & FSI & Permissible Use \\
\hline Old City & 2 & $\begin{array}{l}\text { Residential, } \\
\text { Mercantile-1, } \\
\text { Religious }\end{array}$ \\
\hline Residential & 1.2 & $\begin{array}{l}\text { Residential-1, } \\
\text { Residential-2, } \\
\text { Mercantile-1, } \\
\text { Educational-1, } \\
\text { Religious }\end{array}$ \\
\hline Residential Mix & $1.2+0.3$ & $\begin{array}{l}\text { Residential-1, } \\
\text { Residential-2, } \\
\text { Mercantile-1, } \\
\text { Educational-1, } \\
\text { Religious }\end{array}$ \\
\hline Commercial Mix & & \\
\hline Recreational & 0.9 & $\begin{array}{l}\text { Mercantile-1, } \\
\text { Wholesale, } \\
\text { Religious }\end{array}$ \\
\hline Heritage Overlay & - & $\begin{array}{l}\text { Parks, Leisure } \\
\text { Residential, } \\
\text { Educational-1 }\end{array}$ \\
\hline
\end{tabular}

Table 2. Development Control Regulation

\section{RESULTS AND DISCUSSION}

\subsection{Population Projection}

In order to estimate the population projection for the coming years, a statistical extrapolation was performed on existing population data starting from 1971 . The decadal growth rate, as depicted in Figure 8, indicates the rising trend in the population of Mehmedabad. A floating population of 5000, which primarily constitutes the tourists, has also been incorporated in this analysis. The expected resident population for the year 2031 was found to be around 52203. The extrapolation result could be varied by using higher order polynomials. However, to make the population projection analysis less complicated, a simplistic linear model has been used.

Population Growth

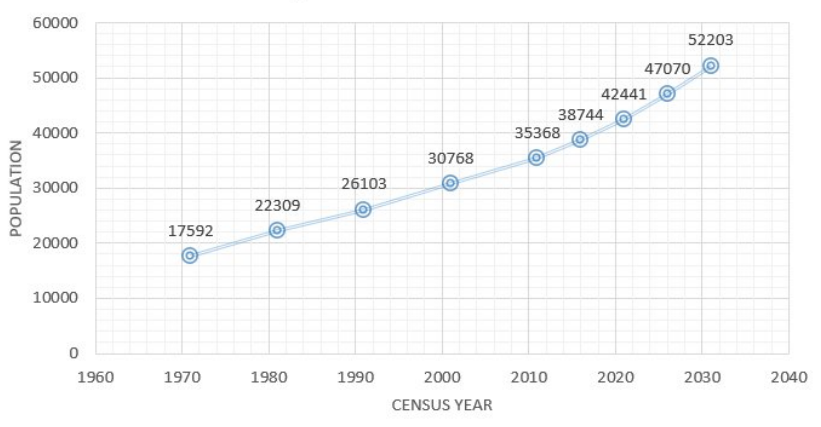

Figure 8. Mehmedabad's population growth trend

\subsection{Infrastructure Design and Costing}

Infrastructure design of water supply and road networks is based on providing suitable coverage. To prepare this, the existing infrastructure was mapped and contour was generated to check the slope. The population distribution was kept in mind as per the zones. A channelisation of both the networks has been carried out in the best possible way to cater to the future demands of the city. Apart from this, the costing has also been carried out by following the Central Public Health and Environmental Engineering Organisation (CPHEEO) and Urban development plans formulation and implementation (UDPFI) guidelines whereby predefined standardised rates provided by these organisations have been used (MOHUA, 2017; MoUD, 2015).

4.2.1 Water Supply: Based on the population projection, the growth of the city and the contour, the water supply network has been considered wherein an additional water requirement of 3.61 MLD (million litres per day) would be necessary if the extraneous population of 16835 is considered (Table 3 ). The water supply locations are shown in Figure 9.

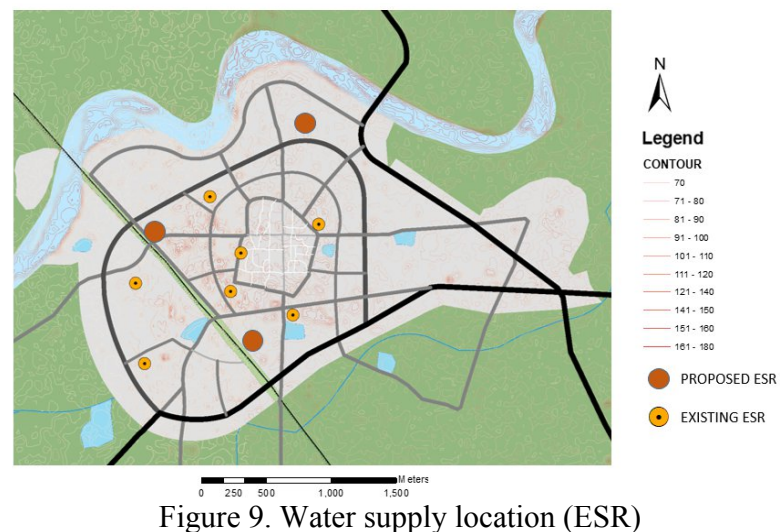

The total length of the trunk line was calculated in GIS and then per meter rates (INR 2000/m) of construction were considered to get an overall idea of the water trunk line cost. The cost of the trunk line was INR 83 million for $41.52 \mathrm{~km}$. Also, the total estimated cost for the four proposed elevated service reservoirs 
(ESR) having a storage capacity of 2 MLD each was INR 22 million. Similar cost analysis was also carried out for sewage discharge wherein various parameters like oxidation pond capacity, pond area, sewage treatment plant capacity, and area were considered. In this case, the expected total cost was found to be INR 140 million.

\begin{tabular}{|l|l|l|l|l|}
\hline \multicolumn{5}{|c|}{ Water Supply and Network Projection } \\
\hline & Population & $\begin{array}{c}\text { Per } \\
\text { capita } \\
\text { Demand } \\
\text { (lpcd) }\end{array}$ & $\begin{array}{c}\text { Water } \\
\text { Demand } \\
\text { (MLD) }\end{array}$ & $\begin{array}{c}\text { To be } \\
\text { supplied } \\
\text { (MLD) }\end{array}$ \\
\hline $\begin{array}{l}\text { Existing } \\
\text { Population }\end{array}$ & 35368 & 135 & 4.77 & 5.49 \\
\hline $\begin{array}{l}\text { Projected } \\
\text { Population }\end{array}$ & 52203 & 135 & 7.05 & 8.10 \\
\hline $\begin{array}{l}\text { Additional } \\
\text { population }\end{array}$ & 16835 & 135 & 2.27 & 2.61 \\
\hline & & & & $\mathbf{3 . 6 1}$ \\
\hline
\end{tabular}

Table 3. Demand and supply of water

4.2.2 Road Infrastructure Cost: The total length of each road has been calculated in GIS along with the total area to be developed. As per the cost per sq. $\mathrm{m}$, the cost of individual roads has been illustrated in Table 4 .

\begin{tabular}{|c|c|c|c|c|}
\hline $\begin{array}{l}\text { Width } \\
\text { (m) }\end{array}$ & $\begin{array}{l}\text { Length } \\
\text { (m) }\end{array}$ & $\begin{array}{l}\text { Total Area } \\
\text { for } \\
\text { Development } \\
\text { (sq. m) }\end{array}$ & $\begin{array}{c}\text { Cost } \\
\left(\mathrm{INR} / \mathrm{m}^{2}\right)\end{array}$ & $\begin{array}{c}\text { Cost/Type of } \\
\text { Road (INR) }\end{array}$ \\
\hline 5 & 4777.10 & 23885.51 & 580 & 13853595.63 \\
\hline 7 & 1394.50 & 9761.50 & 600 & 5856899.92 \\
\hline 9 & 422.49 & 3802.45 & 620 & 2357520.602 \\
\hline 12 & 5229.97 & 62759.60 & 667 & 41860656.51 \\
\hline 18 & 274.74 & 4945.23 & 1028 & 5083701.469 \\
\hline 24 & 34808.83 & 835411.94 & 1383 & 1155374718 \\
\hline 30 & 6720.64 & 201619.33 & 1370 & $\begin{array}{l}276218483.3 \\
\text { 1500.6 } \\
\text { Million }\end{array}$ \\
\hline
\end{tabular}

Table 4. Road Network Projection and Costing

\subsection{D Visualisation of Existing Scenario}

Google Sketchup 3D model (level of detail 1) of the existing scenario was prepared for the study to understand the morphology, scale, and elements. A walkthrough of the old city of Mehmedabad was also built to envisage the road and household infrastructures. In essence, this model (Figure 10) was built to understand the existing scenario of the city. Further

analysis using proper $3 \mathrm{D}$ algorithms for roads and buildings are left as future work.

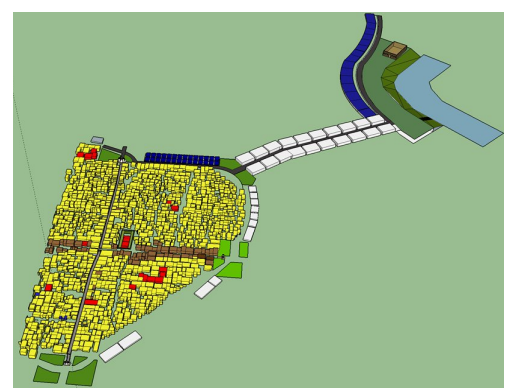

Figure 10. 3D View of Existing Scenario

\subsection{Road Hierarchy and Connectivity}

In a city, roads are considered as the backbone of the city which connect the people living in a particular area, thereby generating the economy and making the place lively. As the existing road network of Mehmedabad has no hierarchy, it leads people to dead ends and different paths. It also lacks sign boards due to which people get misguided. So, it was important to improve the existing road network and resolve these issues. Figure 11.a and 11.b shows the existing and proposed road networks with improved hierarchy respectively. The proposed road sections are displayed in Figure 11.c. It gives the overview of the cross section elements like the footpath, road divider, the number of lanes, built use types which are represented by commercial (blue) and residential (yellow) and the building heights for different categories of roads falling under different zones. Also, the primary and secondary nodes are highlighted in Figure 11.d.

a)

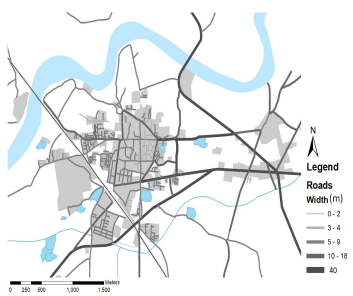

b)

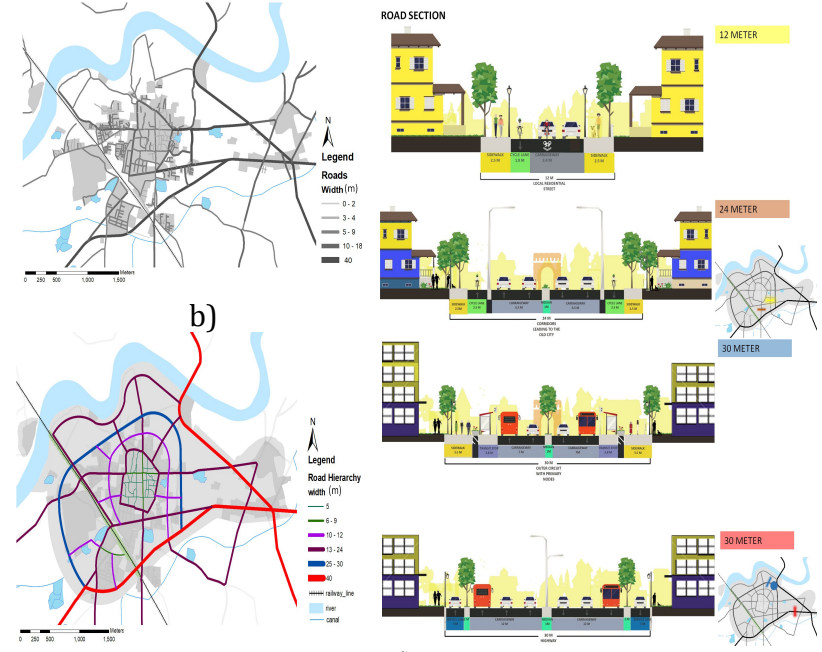

d)

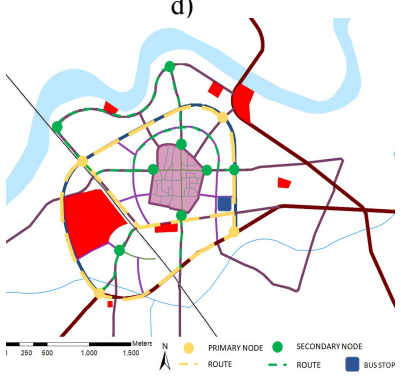

Figure 11. a) Existing road hierarchy b) Proposed Road Hierarchy c) Proposed Road Sections d) Primary and Secondary Transit Nodes 
Essentially, the primary nodes would be located on the boundary of the city. The main purpose of such a node would be to behave as an intermediate node to exit or enter the city and also be an interchange between transit modes, e.g., from rickshaw to bus. These nodes would also serve as intermediate points on the circuit surrounding the core city on which the bus would keep circulating. On the other hand, the secondary nodes would be located near the important places in the city to connect to the core of the city and the important places scattered around it. These would be formal para-transit systems that exclude usage of heavy vehicles.

\subsection{Proposed Land Use Zoning}

Once the road network was fixed, based on the population projection, the past and existing growth patterns of the city and the land use were considered to perform the city zoning operation. Figure 12.a shows the proposed land use of the city, whereby the pie chart represents the percentage land use zoning distribution of the proposed area.

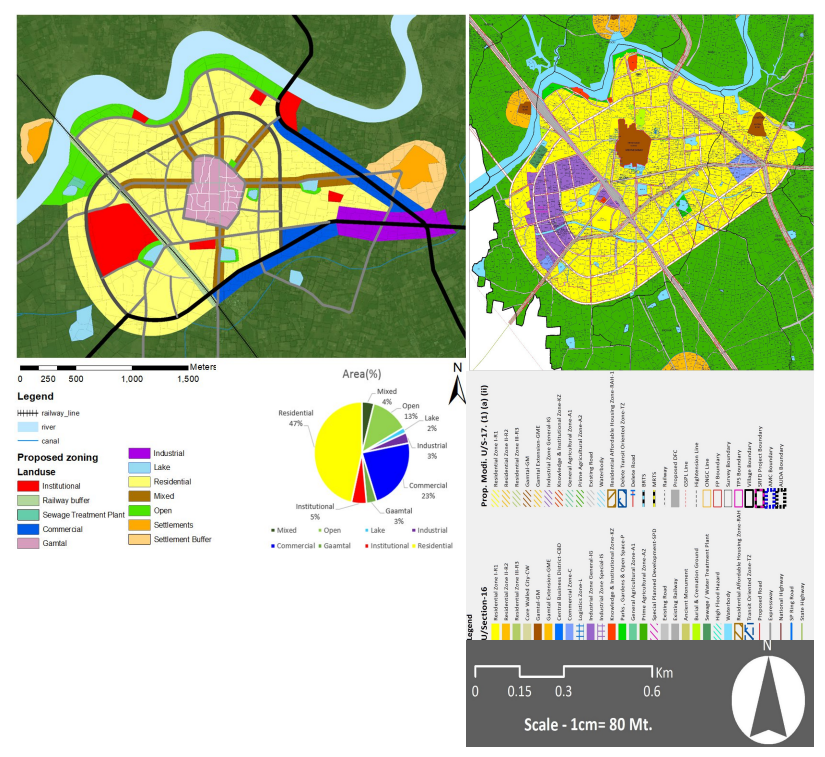

a)

b)

Figure 12. a) Proposed Landuse b) AUDA proposed Landuse

The AUDA DP (Figure 12. b) has been prepared by only considering the regional context and growth trend of Mehmedabad in to account. Hence, we can observe lack of consideration of the existing scenario and other inherent factors of the city. Despite the fact that the industries are on the eastern part of Mehmedabad, AUDA in its DP 2021 has proposed industries on the west. It has been allocated in a similar manner in previous DPs also. Additionally, the area under development in previous development plans is much higher than the demand. Their projected populations are larger because of their expectations of higher industrial development. It has ignored the strengths of the city and failed to acknowledge the heritage, community interaction, pre-dominance of residential development, cheaper land prices, etc. Instead, the proposed development plan, as part of the exercise, has emphasized the existing scenario, thereby proposing the development based on enhancing the strengths of the city. It has focused on the heritage, connectivity, and quality of life of the city residents. The major differences between these plans are a) commercial zone on the state highways (SH)-210 and SH-3 (it was observed that most of the informal commercial activities happen in this area), b) open space on the bank of the Vatrak river and c) industrial zone on the state $\mathrm{SH}-210$ and $\mathrm{SH}-3$. These state highways are viewable in Figure 7.a.

\section{CONCLUSION}

In this work, an attempt has been made to determine the best policies for the city of Mehmedabad by following a grass root oriented approach. Data from individual households were collected to produce an optimal framework for subsequent policy development. In order to improve the quality of life, employment generation and activity generation in the city, the heritage sites have been considered as the cornerstones for the urban planning process. The development control regulations for the micro level were considered specifically for the commercial streets, permissible uses for rejuvenation and development, community spaces and parking. One of the proposed DCRs was to pedestrianise the axial pattern of the old city, as the main junction in the heart of the city fabric faces a lot of chaos and congestion owing to the vehicle movement and also due to pedestrianisation of the road ( 5 meter width). At the macro level, DCRs have been formulated for the residential zone, mixed use corridor (which directly leads to the heart of the city) and the commercial corridor. The various micro and macro level policies that were framed out for Mehmedabad needed to be coupled together, for which $3 \mathrm{D}$ visualisation of the existing scenario was a prerequisite. Since the city facilitates rich cultural heritage sites and the core part of the city is surrounded by four gates (which directly gives access to the people), separate frameworks in the form of individual projects were also considered so as to conserve these gates and at the same time allow access to the area surrounded by the gates. As part of future work, a 3D visualisation and analysis for the entire city could be carried out to identify any additional issues that the city might face post 2031 .

\section{REFERENCES}

Adda, P., Mioc, D., Anton, F., Mcgillivray, E., Morton, a, Fraser, D., ... Vi, W. G. (2010). 3D Flood-Risk Models of Government Infrastructure. 1st International Workshop on Pervasive Web Mapping, Geoprocessing and Services, XXXVIII-4, 6-11.

\section{AUDA. (2016). General Development Control}

Regulations - A. Retrieved from

http://www.auda.org.in/uploads/Assets/rdp/commongder 08012016052529533.pdf

AUDA. (2018). AUDA. Retrieved July 10, 2018, from http://www.auda.org.in/

Balbo, M. (1993). Urban Planning and the Fragmented City of Developing Countries. Third World Planning Review, 15(1), 23.

https://doi.org/10.3828/twpr.15.1.r4211671042614mr

Beatriz, E. D., Molnar, B. E., Griffith, J. L., \& Salhi, C. (2018). Urban-rural disparity and urban population growth: A multilevel analysis of under-5 mortality in 30 sub-Saharan African countries. Health \& Place, 52, 196-204.

https://doi.org/10.1016/j.healthplace.2018.06.006 
Bhagat, R. B., \& Mohanty, S. (2009). Emerging pattern of urbanization and the contribution of migration in urban growth in India. Asian Population Studies, 5(1), 5-20. https://doi.org/10.1080/17441730902790024

Brasebin, M., Perret, J., Mustière, S., \& Weber, C. (2018). 3D urban data to assess local urban regulation influence. Computers, Environment and Urban Systems, $68,37-52$.

https://doi.org/10.1016/j.compenvurbsys.2017.10.002

Census of India. (2011a). Census of India 2011 Urban Agglomerations and Cities Definitions.

Census of India. (2011b). Provisional Population Totals.

Colby, S. L., \& Ortman, J. M. (2015). Projections of the size and composition of the US population: 2014 to 2060: Population estimates and projections. Current Population Reports. Retrieved from http://www.census.gov/content/dam/Census/library/publi cations/2015/demo/p25-1143.pdf

Dell’Unto, N., Landeschi, G., Leander Touati, A.-M., Dellepiane, M., Callieri, M., \& Ferdani, D. (2016). Experiencing Ancient Buildings from a 3D GIS Perspective: a Case Drawn from the Swedish Pompeii Project. Journal of Archaeological Method and Theory, 23(1), 73-94. https://doi.org/10.1007/s10816-014-9226-7

Ehrlich, P. R., \& Holdren, J. P. (1971). Impact of Population Growth. Science, 171(3977), 1212-1217. https://doi.org/10.1126/science.171.3977.1212

Gong, F.-Y., Zeng, Z.-C., Zhang, F., Li, X., Ng, E., \& Norford, L. K. (2018). Mapping sky, tree, and building view factors of street canyons in a high-density urban environment. Building and Environment, 134, 155-167. https://doi.org/10.1016/j.buildenv.2018.02.042

Koziatek, O., Dragićević, S., \& Li, S. (2016). Geospatial Modelling Approach for 3D Urban Densification Developments. In ISPRS - International Archives of the Photogrammetry, Remote Sensing and Spatial Information Sciences (Vol. XLI-B2, pp. 349-352). Prague, Czech Republic. https://doi.org/10.5194/isprsarchives-XLI-B2-349-2016

M. Rumor, V.Coors, E.M. Fendel, S. Z. (2007). Urban Data Management. Taylor \& Francis.

MOHUA. (2005). Jawaharlal Nehru National Urban Renewal Mission: Formulation of a City Development Plan. Retrieved from http://documents.gov.in/central/15523.pdf

MOHUA. (2017). Schemes / Programmes : Ministry of Housing and Urban Affairs, Goverment of India. Retrieved April 27, 2018, from http://mohua.gov.in/cms/schemes-or-programmes.php
MoUD. (2015). Urban and Regional Development Plans Formulation and Implimentation (URDPFI) Guidelines. Ministry of Urban Development (MoUD) (Vol. I). Retrieved from http://moud.gov.in/URDPFI

Peterson, S. H., \& Donaldson, P. (1984). Population Growth and Economic Development. Asia-Pasific Population Journal (Vol. 1). Princeton University Press. https://doi.org/10.15640/jeds.v5n2a9

Polys, N., Newcomb, C., Schenk, T., Skuzinski, T., \& Dunay, D. (2018). The value of 3D models and immersive technology in planning urban density. In Proceedings of the 23rd International ACM Conference on 3D Web Technology - Web3D '18 (pp. 1-4). New York, New York, USA: ACM Press. https://doi.org/10.1145/3208806.3208824

Scianna, a, \& Ammoscato, a. (2010). 3D Gis Data Model Using Open Source Software. ISPRS Archive Vol. XXXVIII, Part 4-8-2-W9, "Core Spatial Databases Updating, Maintenance and Services - from Theory to Practice”, Haifa, Israel, 2010, XXXVIII, 120-125.

World Vision International. (2016). Making Sense of the City: Developing evidence through action research and learning $\mid$ ALNAP. Retrieved from https://www.alnap.org/help-library/making-sense-of-thecity-developing-evidence-through-action-research-andlearning

Xia, Z., \& Qing, Z. (2006). Applications of 3D City Models Based Spatial Analysis To Urban Design. The International Archives of the Photogrammetry, Remote Sensing and Spatial Information Sciences. Retrieved from http://www.isprs.org/proceedings/xxxv/congress/comm2/ papers/148.pdf

Yeh, A. G.-O. (2005). Urban planning and GIS. In Geographical Information Systems: Principles, Techniques, Management and Applications (p. 404). Retrieved from http://masters.dgtu.donetsk.ua/2014/igg/gyulumyan/librar y/tem6.pdf 